\title{
Fish as bioindicators of brackish ecosystem health: integrating biomarker responses and target pollutant concentrations
}

\section{Les poissons, bioindicateurs de la santé d'écosystèmes saumâtres : réponses intégrées de biomarqueurs et concentrations de polluants cibles}

\author{
Ilaria Corsi *, Michela Mariottini, Cristiana Sensini, Lucia Lancini, Silvano Focardi \\ Dipartimento di Scienze Ambientali, Università degli Studi di Siena, Via delle Cerchia, 3-53100 Siena, Italy
}

Received 31 July 2002; accepted 30 September 2002

\begin{abstract}
Biological responses and contaminant levels in biological tissues were investigated in fish specimens of grass goby (Zosterisessor ophiocephalus) collected in spring 2000 in a moderately polluted brackish ecosystem, the Orbetello lagoon (southern coast of Tuscany, Italy). The complexity of harmful effects that contaminants may cause in fish over time was assessed. General condition indices (somatic liver index, and gonadal somatic index), cytochrome P450 enzymes, acetylcholinesterase activity and ovarian morphology were integrated with the content of organochlorines (OCs - hexachlorobenzene, DDTs and polychlorinated biphenyls) in liver and ovaries and $p$-nonylphenol (NP) and lower ethoxylate $\left(\mathrm{NPE}_{1-2}\right)$ content in muscle and ovaries as well. Samples collected from the western basin of the lagoon near the Orbetello sewage treatment plant had somatic liver index values and two P450 activities significantly higher than those collected from the same basin at the Albegna river delta and in the Ansedonia canal in the eastern basin $(P<0.05)$. On the other hand, while muscle content of $p$-NP and NPE $1-2$ was significantly higher in samples from the Orbetello and Albegna river sites than in samples from the Ansedonia canal site, OC levels in liver (DDTs > PCBs > HCB) were particularly lower in samples from STP compared to levels detected in sites AC and AR. Light microscopy of ovaries revealed that although the gonads were sexually mature, the diameter of the oocytes and eggs was smaller than that commonly reported. High levels of OCs and NPs were, in fact, observed in grass goby ovaries, and the differences observed between acetylcholinesterase activities among investigated sites suggest exposure to insecticides as well. The integration of biological responses and contaminant tissue content reveals that certain areas of the lagoon are selectively impacted by various human activities and helps in distinguishing relationships between biological responses and contaminant load in the lagoon environment.
\end{abstract}

(C) 2003 Éditions scientifiques et médicales Elsevier SAS and Ifremer/CNRS/IRD. All rights reserved.

\section{Résumé}

Les réponses biologiques et les niveaux de contamination des tissus ont été recherchés dans des spécimens de gobies d'herbiers (Zosterisessor ophiocephalus) récoltés au printemps 2000 dans un écosystème saumâtre modérément pollué, la lagune d'Orbetello (côte sud de la Toscane). La complexité des effets nuisibles des contaminants sur les poissons est suivie au cours du temps. Des indices globaux (indice somatique hépatique, indice somatique gonadique), les enzymes du cytochrome P450, l'activité acétylcholinestérase et la morphologie de l'ovaire sont utilisés ainsi que le contenu organochloré (hexachlorobenzène, DDTs et biphényles polychlorinatés) du foie et des ovaires, les teneurs en $p$-nonylphénol et en éthoxylates inférieurs du muscle et des ovaires. Des échantillons provenant du bassin ouest de la lagune près de la station d'épuration d'Orbetello présentent, pour l'indice somatique hépatique et pour les deux activités P450, des valeurs nettement supérieures à celles qui sont relevées dans le même bassin dans le delta de la rivière Albegna et dans le canal Ansedonia dans le bassin est $(P<0,05)$. D'autre part, alors que le contenu des muscles en $p$-nonylphénol et en éthoxylates inférieurs apparaît nettement supérieur dans les échantillons provenant des sites «station d'épuration d'Orbetello » et « rivière Albegna » comparé aux échantillons du site « canal Ansedonia », les niveaux d'organochlorés dans le foie (DDTs > PCBs > HCB) sont particulièrement faibles au site « station d'épuration d'Orbetello » comparé à ceux des sites « canal Ansedonia » et « rivière Albegna ». L'examen microscopique des ovaires révèle que, même si

\footnotetext{
* Corresponding author.

E-mail address: corsii@unisi.it (I. Corsi).
} 
les gonades sont sexuellement mûres, le diamètre des oocytes et des œufs est plus petit qu'habituellement. De hautes concentrations d'hexachlorobenzènes et de $p$-nonylphenols sont en fait observées dans les ovaires des gobies des herbiers et les différences entre les activités acetylcholinestérase des différents sites suggèrent une exposition aux insecticides. L'intégration des réponses biologiques et du contenu tissulaire en contaminants indique que certaines aires de la lagune subissent un impact sélectif des activités humaines. Ceci met en évidence les relations entre les réponses biologiques et la charge en contaminants dans l'environnement lagunaire.

(c) 2003 Éditions scientifiques et médicales Elsevier SAS and Ifremer/CNRS/IRD. Tous droits réservés.

Keywords: Biomarkers; Lagoon; Fish; Ovarian histology; Organochlorines; Nonylphenols

Mots clés : Biomarqueurs ; Lagunes ; Poissons ; Histologie des ovaires ; Organochlorés

\section{Introduction}

Lagoon ecosystems, like most brackish environments, are biotopes of great ecological value, characterised by high biodiversity and trophic migrations, which could be at risk without appropriate management and risk assessment (Cognetti and Maltagliati, 2000). Since in such delicate semiclosed ecosystems, environmental and ecological factors may influence or drastically modulate the response of organisms to particular stressors, like contaminants, it is more difficult to identify relationships between contaminants and organism responses (Adams et al., 1989, 1999).

In order to assess the ecological risk and the causal or correlative relationship between the health of organisms and environmental contaminant levels in a brackish environment, female specimens of a sentinel fish species, the grass goby (Zosterisessor ophiocephalus), were collected from three areas of a moderately human-impacted lagoon on the southern coast of Tuscany, the Orbetello lagoon. The Orbetello lagoon is a significant example of a brackish environment regardless of its small size, weak hydrodynamism and shallow waters, which limit exchange with seawater (Bucci et al., 1988; Innamorati, 1998). The nutrient enrichment of sediment and/or the retention of toxic compounds are mainly related to pollution, although there are few industrial activities carried out in the area. Recently, the lagoon was declared a "High Environmental Risk Area" by the Italian Ministry of Environment. In fact, urban waste released from the sewage treatment plant (STP), pesticides, agricultural runoff from the Albegna river Fig. 1 and discharges from several aquaculture facilities along the Ansedonia and Nassa canals may have cumulatively negative effects on the environmental quality of the waters, in which decreased biodiversity and accidental fish die-offs have occurred (Lardicci et al., 1997; Cognetti and Maltagliati, 2000). The recent development of economic activities such as intensive and extensive fish farming is now impacting the lagoon, as fish feed residues and metabolites are directly discharged into the waters. Tourism in spring and summer results in increased urban wastewater, coupled with insufficient clearance capability of the only STP in Orbetello, located off the shores of the western basin (Innamorati, 1998; Corsi and Focardi, 2002). Furthermore, the lagoon and the surrounding areas underwent malaria eradication by the use of dichlorodiphenyltrichloroethane

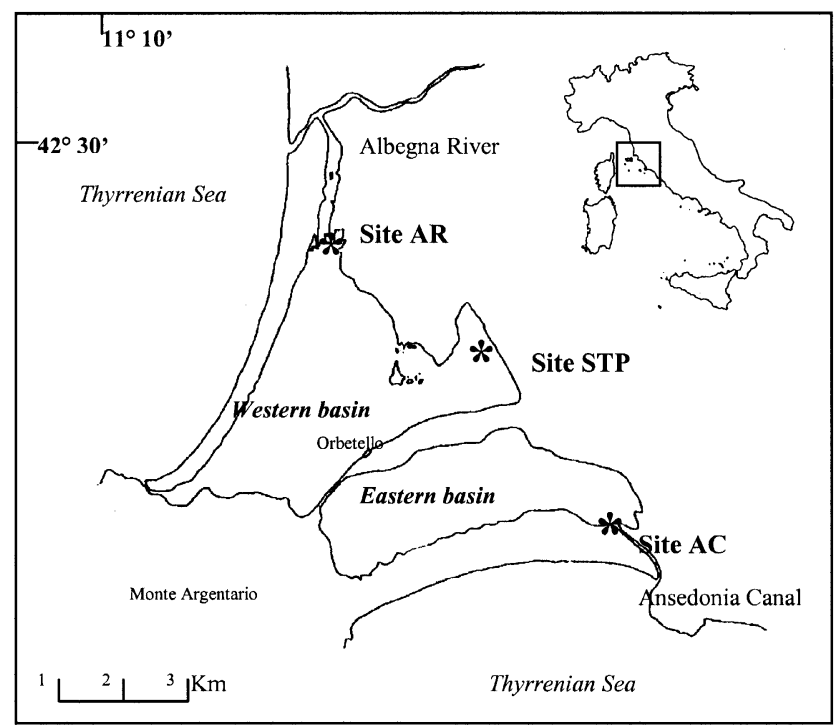

Fig. 1. Sampling sites in the Orbetello lagoon: STP in the western basin, AC site on $\mathrm{AC}$ in the eastern basin and $\mathrm{AR}$ site at the $\mathrm{AR}$, also in the western basin.

(DDT) immediately after World War II, and this continued into the 1950s (Romi et al., 2001).

Aquatic toxicology normally focuses on changes at the toxicokinetic level and on measuring contaminant concentrations in biological tissues to assess exposure levels and bioaccumulation patterns. An integrated approach of selected biological responses was therefore implemented to investigate site-specific associations between biological responses and bioaccumulation of the most common aquatic pollutants. Bioindicators of the health of individual fish included a general condition index, the somatic liver index (SLI), specific biomarkers of contaminant exposure such as two cytochrome P450 enzyme activities, like 7-ethoxyresorufin- $O$ deethylase (EROD) and benzo $(a)$ pyrene monooxygenase (BaPMO), and acetylcholinesterase activity (AChE). Indicators of reproductive competence, like gonadal somatic index (GSI) and histology of ovaries, which are particularly sensitive to a variety of environmental contaminants, were also included. In brackish ecosystems, assessing exposure to other factors that can have detrimental effects on fish ovarian development and spawning is especially important, since it is in these environments that genetic diversity and ecological processes (reproduction, recruitment, nursery and fattening) 
are maintained (Johnson et al., 1988; Cognetti and Maltagliati, 2000). While induction of P450 enzyme activities and inhibition of AChE activity are specific markers of exposure to certain pollutants, others, like the histology of ovaries, represent signs of interaction between pollution and physiological processes (Depledge and Fossi, 1994; Walker, 1998; Ham et al., 1997; Adams et al., 1999). The mixed function oxidase system P450 is known to play a major role in the oxidative metabolism/biotransformation of toxic compounds such as chlorinated and aromatic hydrocarbons. Both EROD and BaPMO activities are, in fact, widely used in environmental exposure assessments to polychlorinated biphenyls (PCBs) and PAHs in a variety of fish species, including grass goby (Z. ophiocephalus) (Goksøyr and Förlin, 1992; Goksøyr, 1995; Livingstone, 1996; Nasci et al., 1985, 1991; Livingstone et al., 1995). The AChE enzyme activity also represents a more specific marker of exposure to agricultural pesticides such as organophosphate (OP) and carbamate (CB) insecticides. However, $\mathrm{AChE}$ is recently emerging as a more general marker of exposure to other neurotoxic contaminants such as heavy metals and organochlorines (OCs) (Galgani and Bocquené, 1990; Gill et al., 1990a, b; Sturm et al., 1999; Fulton and Key, 2001). The histology of ovaries was therefore investigated for endocrine disruption and to evaluate its potential use as a biomarker of endocrine disruption in wild fish (Tricklebank, 2001).

Contaminant concentrations were assessed in biological tissues by measuring liver content of hexachlorobenzene (HCB), DDTs and PCBs, while $p$-nonylphenol ( $p$-NP) and lower ethoxylates $\left(\mathrm{NPE}_{1-2}\right)$ were measured in muscle, where they accumulate most (Keith et al., 2001). All compounds were also investigated in fish ovaries. NP surfactants are discharged into aquatic environments via urban and industrial wastewater, where they are biologically degraded into the by-products $\mathrm{NPE}_{n}<5$ and into the final degradation intermediate $p$-NP (Talmage, 1994). Evidence of how such hydrophobic metabolites $\left(\log K_{\text {ow }} 4-4.6\right)$, especially $p$-NP and its lower oligomers $\left(\mathrm{NPE}_{1-3}\right)$, are persistent and toxic to aquatic organisms is increasing (Lewis, 1991), and there are some indications of their oestrogenic properties in sexually mature fish (endocrine disruption) (White et al., 1994; Jobling and Sumpter, 1993). OCs and PCBs are widespread in most environmental compartments as a result of river transport, surface runoff and atmospheric deposition (Porte and Albaigés, 1993). There is growing evidence that these compounds are extremely harmful to marine and freshwater ecosystems, since they are highly persistent and bioaccumulate up aquatic food webs. This is widely documented in fish species in various brackish Mediterranean ecosystems (Pulsford et al., 1995; Focardi et al., 1998). Liver and muscle tissue are used in pollution assessments and for comparison purposes, while concentrations in gonads, like ovaries, are crucial for reproduction (Hellou et al., 1993), since "the early life stages [of biota] are more susceptible to the effects of pollution" (Kime, 1997).
The fish species selected for this study, grass goby (Z. ophiocephalus), is a typical resident bottom-dweller abundant in shallow waters, like the Orbetello lagoon. It is suitable for biomonitoring studies of brackish environments because it can concentrate pollutants to a higher degree than other species, due to the fact that it feeds on sediments and has reduced detoxifying capabilities (Fossato, 1982; Nasci et al., 1991; Livingstone et al., 1995; Pulsford et al., 1995; Pastor et al., 1996).

\section{Material and methods}

\subsection{Study area and sampling}

Sampling was conducted in the Orbetello lagoon, a 2600-ha area on the southern coast of Tuscany (lat. $42^{\circ} 30^{\prime} \mathrm{N}$; long. $11^{\circ} 10^{\prime} \mathrm{E}$ ), bordered by two sandbars. Dividing the lagoon into an eastern basin and a western basin is an isthmus, upon which the town of Orbetello is located. Water from the Albegna river flows into the western basin up north, while the Nassa canal connects it to the sea down south. The eastern basin is connected to the sea by the Ansedonia canal (AC), a narrow inlet limiting the exchange with seawater Fig. 1].

Prespawning female grass gobies of mean length $12.9 \pm$ $2.08 \mathrm{~cm}$ were collected in late spring 2000 using fish traps positioned in three sites of the lagoon: site STP in front of the sewage treatment plant of Orbetello town (western basin), site AC on the Ansedonia canal (eastern basin) and site AR on the Albegna river delta (western basin). Ten fish specimens were collected at every site and sent to the laboratory in oxygenated water tanks with aerated collection-site water. Immediately after being sacrificed, fish were individually weighed and measured. Livers, a portion of dorsal fin and ovaries were excised and weighed individually. The left ovary was stored on ice for histology, while liver, muscle, gill and brain tissues and right ovary were flash frozen in liquid nitrogen and stored at $-80{ }^{\circ} \mathrm{C}$ for enzyme assays and at $-20{ }^{\circ} \mathrm{C}$ for chemical determinations. SLI and GSI were calculated according to the following formulas: SLI $=$ (liver weight $(\mathrm{g}) /$ body weight $(\mathrm{g})) \times 100$ and GSI $=($ ovary weight $(\mathrm{g}) /$ gutted body weight $(\mathrm{g})) \times 100$.

\subsection{Laboratory procedures}

About $1 \mathrm{~g}$ of liver tissue was used for enzyme analysis prior to microsome extraction in sucrose buffer in 1:4 ( $\left.\mathrm{w} \mathrm{v}^{-1}\right)$ proportion ( $50 \mathrm{mM} \mathrm{K}_{2} \mathrm{HPO}_{4}, 75 \mathrm{mM}$ sucrose, $1 \mathrm{mM}$ EDTA, $0.5 \mathrm{mM}$ DTT and $400 \mu \mathrm{M}$ PMSF, $10 \mu \mathrm{M}$ Leupeptin, $1 \mu \mathrm{M}$ Pepstatin and $1 \mathrm{mg} \mathrm{ml}^{-1}$ Aprotinin) $\mathrm{pH} 7.5$ at $4{ }^{\circ} \mathrm{C}$, first centrifuged at $9000 \mathrm{~g}$ for $20 \mathrm{~min}$ and run through a second centrifuge at 100,000 $g$ for $1 \mathrm{~h}$. The pellet was resuspended in $10 \mathrm{mM}$ Tris buffer, 20\% $\mathrm{w} \mathrm{v}^{-1}$ glycerol, $0.5 \mathrm{mM}$ DTT, $1 \mu \mathrm{M}$ Pepstatin, $10 \mu \mathrm{M}$ Leupeptin, $1 \mathrm{mg} \mathrm{ml}^{-1}$ Aprotinin and $400 \mu \mathrm{M}$ PMSF $\left(\mathrm{pH} 7.5, T 4{ }^{\circ} \mathrm{C}\right.$ ) and stored at $-80{ }^{\circ} \mathrm{C}$ until analysis. The isolated microsomal fraction was then used to determine both EROD and BaPMO activities by the spectrof- 
luorimetric method of Burke and Mayer (1974) and the fluorimetric method of Kurelec et al. (1977), respectively. The amount of resorufin used for EROD assay was calculated from a pure reference resorufin standard calibration curve with a detection limit of $0.05 \mathrm{pmol} \mathrm{min}^{-1} \mathrm{mg}$ proteins ${ }^{-1}$. The EROD activity was expressed as pmol $\mathrm{min}^{-1} \mathrm{mg}$ proteins ${ }^{-1}$.

The BaPMO fluorimetric assay was carried out according to the method of Nebert and Gelboin (1968) as modified by Walters et al. (1979). The activity was expressed as unit of fluorescence (U.F.) $\mathrm{min}^{-1} \mathrm{mg}$ proteins ${ }^{-1}$. A Perkin Elmer LS $50 \mathrm{~B}$ spectrophotofluorimeter was used in both assays; each sample was done in triplicate.

$\mathrm{AChE}$ activity was measured in brain and gill tissues according to the colorimetric method of Ellmann et al. (1961). Assay components included: $25 \mathrm{mM}$ Tris- $\mathrm{HCl}$ buffer (pH 7.6, containing $\left.1 \mathrm{mM} \mathrm{CaCl}_{2}\right)$, DTNB $(0.333 \mu \mathrm{M}$, final concentration) and 200-250 $\mu \mathrm{l}$ of sample supernatant, in a total volume of $3 \mathrm{ml}$. The reaction was initiated by adding ATCI $(277 \mu \mathrm{M}$ final concentration) and the progressive increase in absorbance recorded for $5 \mathrm{~min}$ at $410 \mathrm{~nm}$ in a UV spectrophotometer. Activity was calculated as micromoles of substrate hydrolysed $\mathrm{min}^{-1} \mathrm{mg}$ proteins ${ }^{-1}$. Total protein content (microsomes and gill and brain tissue) was measured by the method of Bradford (1976). Visible recording spectrophotometer $\lambda 595 \mathrm{~nm}$, Biorad Protein and bovine serum albumin (BSA), as reference standard, were used.

For histological examination, left ovaries were fixed in Bouin's fluid for $48 \mathrm{~h}$, resin embedded (Technovit 8100), cut at $3 \mu \mathrm{m}$ with an LKB Ultratome III, stained with Mayer's haemallum and eosin and examined at light microscopy.

The reproductive status of the ovary and the developmental stage of oocytes of the grass gobies were described according to Giulianini et al. (1994).

The extraction and quantitation method for NP analysis was as modified by Marcomini et al. (1990). High-purity standards (>99\% purity) of $p$-NP were obtained from Fluka, while ethoxylates $\left(\mathrm{NPE}_{1-2}\right)$ were obtained from Condea (commercial mixture: Nonfix2). Portions of dorsal muscle and left ovary Soxhlet digested in $n$-hexane $(16 \mathrm{~h})$ were concentrated by solid phase extraction (LC-NH2 cartridge) and injected (50-200 $\mu \mathrm{l}$ ) into a liquid chromatograph (Waters) connected to a UV spectrophotometer at $277 \mathrm{~nm}$. Prepacked spherical $3 \mu \mathrm{m}$ aminopropylsilica columns (Hypersil APS, $100 \times 4 \mathrm{~mm}$ i.d., Supelco ${ }^{\circledR}$ ) were used. 2,4,6Trimethylphenol was added to the extracts as internal standard. Spiked samples showed recoveries greater than $90 \%$ for both $p$-NP and $\mathrm{NPE}_{1-2}$. The limit of quantification was $0.01 \mathrm{ng} \mathrm{g}^{-1}$ on $1 \mathrm{~g}$ of fresh tissue. Residues are reported on a wet weight (w.w.) basis.

OC pesticides and PCBs were extracted according to Wakimoto et al. (1971). Portions of liver and ovary Soxhlet digested in $1 \mathrm{~N} \mathrm{KOH} /$ ethanol $(1 \mathrm{~h})$ were transferred to $n$-hexane and cleaned in a $1.5 \mathrm{~g}$ silica gel (63-200 mesh size), packed in a glass column $(10 \mathrm{~mm}$ i.d. $\times 20 \mathrm{~cm})$. This method transforms $p, p^{\prime}$-DDT to $p, p^{\prime}$-DDE and decomposes $p, p^{\prime}$-DDD by alkaline treatment. DDT values are the sum of $p, p^{\prime}$-DDT and $p, p^{\prime}$-DDE ( $\Sigma$ DDT). Columns were eluted with $200 \mathrm{ml}$ of $n$-hexane, and the eluates were concentrated and analysed by gas chromatography with a Perkin Elmer Autosystem gas chromatograph fitted with a ${ }^{63} \mathrm{Ni}$ electron capture detector using an SBP-5 capillary column (Supelco) $(30 \mathrm{~m}, 0.25 \mathrm{~mm}$ i.d., $0.25 \mu \mathrm{m}$-thick coating). A mixture of HCB, $p, p^{\prime}$-DDE and Aroclor 1260 (Supelco) was used as external standard for calibration, recovery evaluation and confirmation. Blanks were determined before analysis of samples, and their maximum values were subtracted from the results. The concentrations of individually resolved peaks of PCB isomers were summed to obtain total PCB concentrations. The detection limit was $0.01 \mathrm{ng} \mathrm{g}^{-1}$ w.w., and the recoveries ranged from $80 \%$ to $105 \%$. The concentrations of OC compounds and individual PCB congeners were both calculated on a w.w. basis.

\subsection{Statistical analysis}

Data were expressed as mean \pm standard deviation $( \pm$ S.D.). Data were log-transformed for achieving normal distribution before running ANOVAs. Post-hoc Tukey compromise tests were used to determine statistical differences among sampling sites and tissues. A probability level of less than 0.05 was considered significant. Statistical analyses were performed with Statistica 5.1 (StatSoft, USA).

\section{Results and discussion}

As an indication of fish liver metabolic activity, SLI was significantly higher in fish collected off the STP than those from the AC and the Albegna river delta (AR) $(P<0.05)$ Fig. 2). The high SLI values from site STP $(2.24 \pm 1.17)$ are similar to those reported for grass gobies experimentally exposed to $10 \mu \mathrm{g} / \mathrm{l}$ of Aroclor 1260 for $12 \mathrm{~d}(2.39 \pm 0.71)$ and to $10 \mu \mathrm{g} / \mathrm{l}$ of Aroclor 1254 in water and food for $7 \mathrm{~d}(2.23 \pm$ 0.9) (Fossi et al., 1989; Nasci et al., 1985). Wild grass gobies

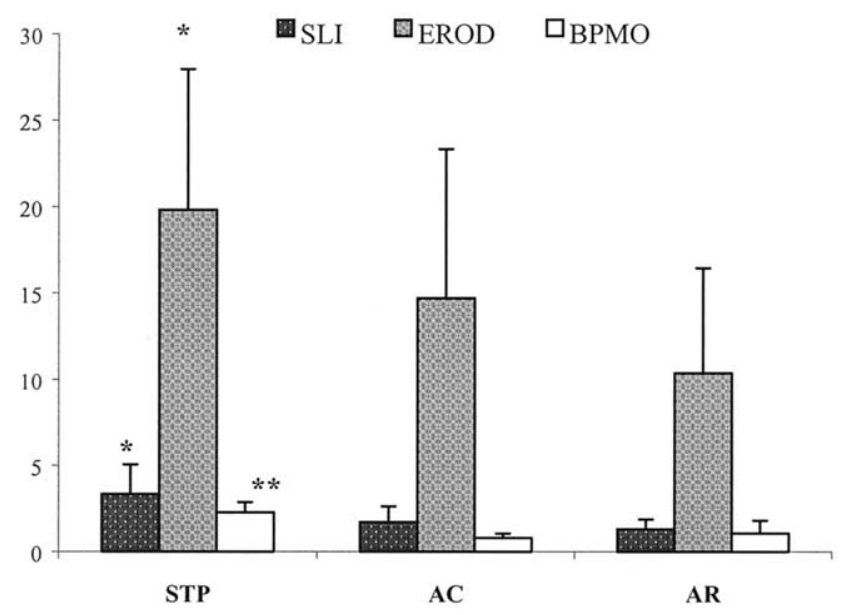

Fig. 2. Liver metabolic activity (SLI) and P450 responses in 10 fish collected from each sampling site $(P<0.05$ marked with $*$ and $P<0.01$ marked with **). 
from a highly industrialised area of the Venice lagoon (Porto Marghera) showed similar SLI values $(2.9 \pm 0.32)$ (Nasci et al., 1991). However, the same authors as well as Casini et al. (1994) reported lower SLI values in grass gobies from areas of the Venice lagoon with low pollution $(1.93 \pm 0.8$ to $1.7 \pm$ 0.7 and $1.7 \pm 0.93$, respectively), as in those measured in fish from the Ansedonia canal (AC, eastern basin). The trend observed for SLI among sampling sites is confirmed by the highest EROD and BaPMO activities recorded in these samples. EROD activities were, in fact, significantly higher in fish from site STP than those in AC fish $(P<0.05)$, while activities of fish from site AR were the lowest Fig. 2). In particular, EROD activities measured in fish from site STP were slightly lower than those reported by Livingstone et al. (1995) for grass gobies collected from one of the most polluted and industrialised areas of the Venice lagoon: Porto Marghera (19.81 \pm 8.14 and $39.6 \pm 0.2 \mathrm{pmol} \mathrm{\textrm {min } ^ { - 1 } \mathrm { mg } \text { pro- }}$ teins $^{-1}$, respectively). Moreover, lower EROD activity, similar to those measured in samples from site AC (eastern basin) and AR, was reported by the same authors for a less polluted site (Lio Grande) $(14.1 \pm 3.4$ and $14.65 \pm$ $8.65 \mathrm{pmol} \mathrm{min}^{-1} \mathrm{mg}$ proteins ${ }^{-1}$, respectively) (Livingstone et al., 1995) and in the urban area of the Venice lagoon (7.0 \pm 6.8 and $10.36 \pm 6.04 \mathrm{pmol} \mathrm{min}^{-1} \mathrm{mg}$ proteins $\mathrm{s}^{-1}$, respectively) (Casini et al., 1994, 1995). While BaPMO activity was again significantly higher in samples from site STP than in fish from site $\mathrm{AC}(P<0.01)$, samples from AC also showed significantly lower levels than those from site AR $(P<0.05)$ Fig. 2. High BaPMO activities observed in grass gobies from site STP were similar to those reported by Nasci et al. $(1985,1991)$ and Casini et al. (1994) for both the highly polluted area of Porto Marghera (2.1 and $2.18 \pm$ 1.53 U.F. $\min ^{-1} \mathrm{mg}$ proteins ${ }^{-1}$ ) and the urban area of the Venice lagoon (2.5 \pm 1.5 U.F. $\mathrm{min}^{-1} \mathrm{mg}$ proteins $\left.{ }^{-1}\right)$.

The consistent liver responses (SLI, EROD and BaPMO activities) among grass gobies collected from site STP seem to indicate the presence of moderate to high levels of contaminant type-P450 inducers in this area and are likely to be related to the release of STP effluents. On the other hand, PCB levels in liver of grass gobies from this site were particularly lower $\left(136.93 \pm 77.18 \mathrm{ng} \mathrm{g}^{-1}\right.$ w.w. $)$ compared to levels detected in fish from sites AC and AR (164.78 \pm 74.95 and $183.35 \pm 173.35 \mathrm{ng} \mathrm{g}^{-1}$ w.w., respectively) Fig. 3 . As seen for PCBs, liver levels of other P450 inducers, like DDTs, were also significantly greater in grass gobies from site AC $\left(359.83 \pm 79.63 \mathrm{ng} \mathrm{g}^{-1}\right.$ w.w.) than in those from sites STP and AR $\left(290.1 \pm 153.23\right.$ and $176.7 \pm 173.4 \mathrm{ng} \mathrm{g}^{-1}$ w.w., respectively) $(P<0.05)$. PCB levels measured in liver of gobies in the present study seemed to be very low when compared to those found in samples from the highly polluted area of Porto Marghera (Venice lagoon) (11,391 and $8863 \mathrm{ng} \mathrm{g}^{-1}$ dry weight (d.w.), respectively), while liver levels of DDTs reported by the same authors were highly comparable (430-283.3 $\mathrm{ng} \mathrm{g}^{-1}$ w.w. as mean level from all three sites in the present study) (Livingstone et al., 1995). Pulsford et al. (1995) found much higher levels of DDTs in

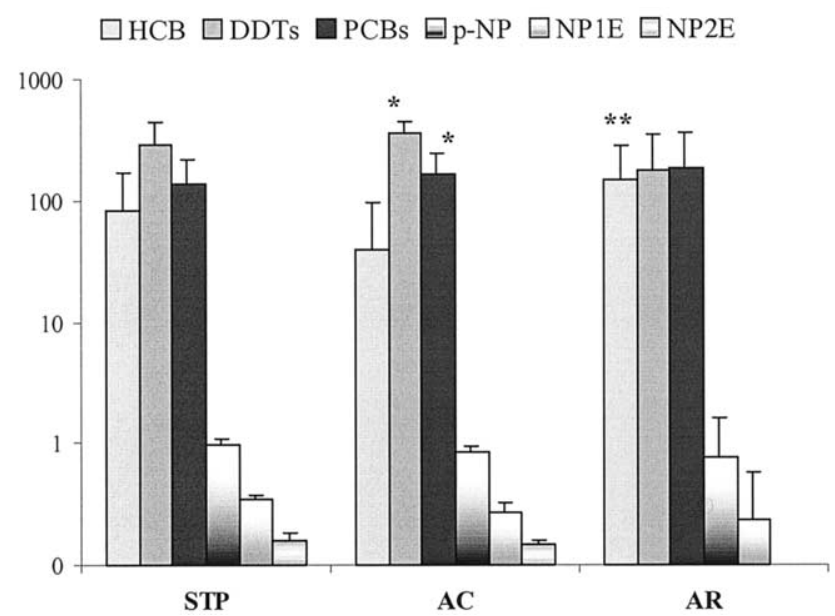

Fig. 3. Organochlorine liver content and NP muscle content in 10 fish collected from each sampling site $(P<0.05$ marked with $*$ and $P<0.01$ marked with **)

liver of gobies collected from the same area in June 1992 (mean: $827 \mathrm{ng} \mathrm{g}^{-1}$ d.w.). The presence of relatively high concentrations of DDTs in the Orbetello lagoon is consistent with the wide use of this compound for malaria eradication from the 1940s to 1950s (Romi et al., 2001). In fact, the OC trend observed here on grass goby liver contents is as follows: DDTs > PCBs >HCB. These results, indicating a moderate OC contamination in site STP, are consistent with those of previous investigations, in which Eljarrat et al. (1999) reported higher PCN and PCDD/F concentrations in sediment collected from the same site $\left(1515.36 \mathrm{pg} \mathrm{g}^{-1}\right.$ d.w.). Jimenez et al. (1998) also detected higher values of PCDDs and PCDFs in sediment and biological samples of Carcinus aestuarii caged off STP, in accordance with our previous investigations showing high $\mathrm{P} 450$ activities as BaPMO and $\mathrm{NAD}(\mathrm{P}) \mathrm{H}$ reductases in crabs collected from this site (Corsi, 1995; Fossi et al., 1996). More evidence on the release of chlorinated hydrocarbons at the STP site comes from a recent study conducted by Eljarrat et al. (1999), where high PCN levels were measured in sediment. In particular, the authors report that although not all the PCN congeners were tested for EROD enzyme induction, those measured are attributed to the mixture Halowax 1014, which has a high content of PCN congeners that induce the P450 system (Villeneuve et al., 2000; Eljarrat et al., 1999).

Even these data show a greater presence of dioxin-like compounds in sediments and invertebrates in site STP; the low levels of PCBs determined in liver of our grass gobies from this site could be related to enhanced detoxifying activities (EROD and BaPMO), as described in other studies (Nasci et al., 1991). In particular, the examination of the GC-ECD PCB fingerprint allowed the identification of 38 individual congeners by comparing their retention times with peaks of the Aroclor 1260 mixture. Since hexachlorobiphenyl no. 153 was usually the highest component, we referred the distribution pattern of selected congeners to it. Hexachlorinated biphenyls such as congeners IUPAC nos. 153, $118+$ 149 and 138 were selectively and highly accumulated in liver 


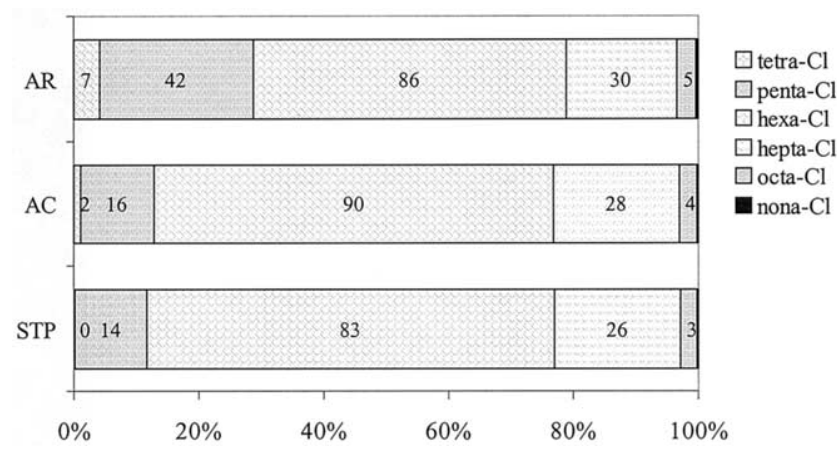

Fig. 4. Percentage of class of isomers from each site: hexachlorobiphenyls and hepta- and pentachlorobiphenyls were most abundant in sites STP and AC. Pentachlorobiphenyls were predominant when compared to heptachlorobiphenyls, representing $25 \%$ of the total PCBs in site AR.

according to the bioaccumulation pattern reported for fish in the literature (Porte and Albaigés, 1993; Corsolini et al., 1995a; Corsi et al., 2001). In fact, hexachlorinated congeners with chlorine atoms in the $2,4,5$ positions in both rings, are less readily metabolised and more persistent (Zell et al., 1978; Porte and Albaigés, 1993; Focardi et al., 1998).

Hexachlorinated biphenyls were, in fact, the most abundant class of isomers in samples from all sites as previously described by Corsolini et al. (1995b) throughout this region and were followed by hepta- and pentachlorobiphenyls only in sites STP and AC. Pentachlorobiphenyls were predominant compared to heptachlorobiphenyls only in AR samples, representing $25 \%$ of total PCBs Fig. 4. Regarding the other compounds measured in grass goby livers, HCB concentrations exhibited relatively low values, ranging from $38.63 \pm$ $55.35 \mathrm{ng} \mathrm{g}^{-1}$ w.w. in samples from AC to $81.9 \pm$ $85.9 \mathrm{ng} \mathrm{g}^{-1}$ w.w. in those from site STP, up to a significantly higher $(P<0.01) 147.37 \pm 130.01 \mathrm{ng} \mathrm{g}^{-1}$ w.w. in samples from AR. Mean HCB levels measured in fish livers from all three sites (84.5 $\mathrm{ng} \mathrm{g}^{-1}$ w.w.), except for those from site AR, were in the range of those reported for fishes collected throughout the Italian coasts ranging from 0.14 to $84.34 \mathrm{ng} \mathrm{g}^{-1}$ w.w. Fig. 3). The association with the upper range of HCB levels is probably related to a relatively high lipid content and to reduced detoxifying capability of the sentinel species, since the grass goby seems to be unable to fully metabolise and excrete HCB (Focardi et al., 1996).

Finally, the trend observed for $p$-NP and $\mathrm{NP}_{1-2}$ muscle content among the three sampling sites revealed a higher $p$-NP content in samples from site STP (0.98 \pm $0.05 \mathrm{ng} \mathrm{g}^{-1}$ w.w.) than levels measured in samples from sites $\mathrm{AC}$ and $\mathrm{AR}\left(0.84 \pm 0.01\right.$ and $0.75 \pm 0.02 \mathrm{ng} \mathrm{g}^{-1}$ w.w., respectively). Although no significant differences were observed among the three sites, the highest levels being measured in samples from site STP is consistent with our previous investigation, in which a greater $p$-NP accumulation in muscle of grass gobies collected off STP was reported (Corsi and Focardi, 2002). Likewise, NP1E muscle content was higher in samples from site STP $\left(0.34 \pm 0.2 \mathrm{ng} \mathrm{g}^{-1}\right.$ w.w. $)$, followed by levels in samples from sites AC and AR (0.27 \pm 0.1 and $0.24 \pm 0.05 \mathrm{ng} \mathrm{g}^{-1}$ w.w., respectively). Regarding

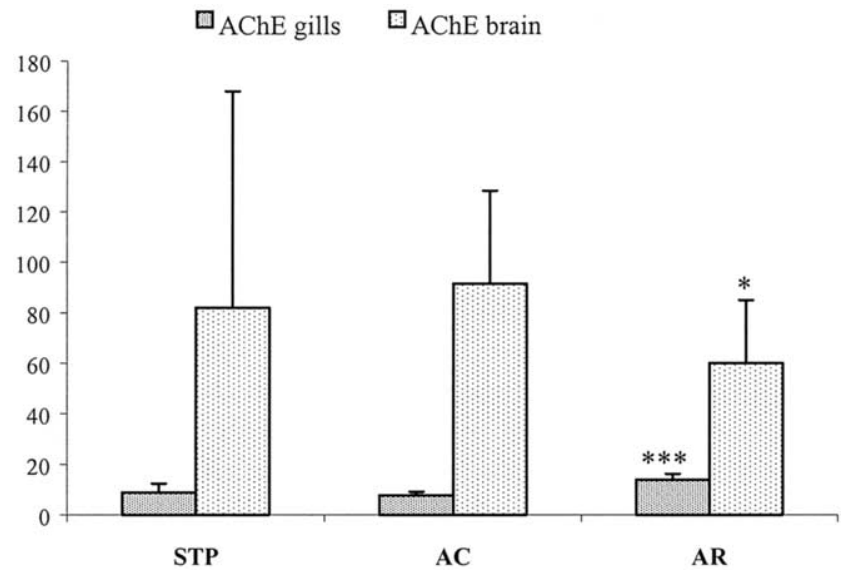

Fig. 5. AChE activity in gills and brain (nmol $\mathrm{min}^{-1} \mathrm{mg}$ proteins $\left.{ }^{-1}\right)$ of $10 \mathrm{fish}$ collected from each sampling site $(P<0.05$ marked with $*$ and $P<0.001$ marked with ***).

NP2E, similar levels were detected in samples from sites STP and $\mathrm{AC}\left(0.16 \pm 0.02\right.$ and $0.15 \pm 0.01 \mathrm{ng} \mathrm{g}^{-1}$ w.w., respectively), while levels in samples from site AR were below the detection limit of $0.01 \mathrm{ng} \mathrm{g}^{-1}$ w.w. Fig. 3. Levels of both $p$-NP and ethoxylates $\left(\mathrm{NPE}_{1-2}\right)$ in grass gobies seem very low compared to those reported by Lye et al. (1999) and Keith et al. (2001) in freshwater fish species from rivers heavily impacted by STP effluents. However, levels may increase seasonally depending on the intensity of stressors in the lagoon and can seriously affect fish health in terms of oestrogenic action and that of humans and wildlife through dietary exposure (Corsi and Focardi, 2002).

A slightly significant positive correlation was observed between NP1E in muscle and EROD activity $(r=0.69)$, while no correlation was observed with HCB and $p$-NP and NP2E. $p$-NP showed a slight correlation with SLI $(r=0.48)$, BaPMO $(r=0.56)$, GSI $(r=0.52)$ and gill AChE $(r=0.52)$. DDTs and PCBs are known potent P450 inducers and, in particular, of EROD activity in fish such as grass goby (Stegeman et al., 1992), while no clear evidence is available on the role of $p$-NP and $\mathrm{NPE}_{1-2}$ on P450 activities, suggesting the need for further investigations.

Regarding biological responses related to $\mathrm{OP}$ and $\mathrm{CB}$ exposure, results on AChE activity showed a different profile among sampling sites both in gills and in brain Fig. 5. Brain AChE activity was significantly lower in samples from site AR $(P<0.05)$, and likewise, those from sites STP and AC were highly comparable. In contrast, gill AChE activities in fish from sites STP and AC were significantly lower $(P<$ 0.001) than in fish from site AR Fig. 5). Brain AChE activity represents a more reliable response to OP insecticide exposure than gills (Habig and Di Giulio, 1991). Differences in time-dependent responses between the two tissues or a different behaviour towards various inhibitors, as reported for other vertebrates and invertebrates (Habig and Di Giulio, 1991; Talesa et al., 2001), may explain the different signals between brain and gill (Fulton and Key, 2001). The lowest activities in samples from the AR might be related to river transport of chemicals from agricultural areas that this river 
Table 1

Mean ( \pm S.D.) oocyte diameter $(\mu \mathrm{m})$ of all grass goby samples collected from the three sites of Orbetello lagoon and in the Upper Adriatic Sea as reported by Giulianini et al. (1994)

\begin{tabular}{llll}
\hline Species & Oocyte stages & Oocyte diameter (Orbetello lagoon) & Oocyte diameter (Upper Adriatic Sea) \\
\hline Z. ophiocephalus & Secondary yolk & $488.8 \pm 12.76$ & $524.0 \pm 30.9$ \\
& Tertiary yolk & $673.6 \pm 37.86$ & $725.8 \pm 57.4$ \\
& Egg & $704.8 \pm 31.20$ & $811.4 \pm 44.9$ \\
\hline
\end{tabular}

crosses, as already reported in previous studies. Predictive models validated by the measurement of AChE activity in grass goby samples from both basins of the Orbetello lagoon recently confirmed a greater pesticide release in the delta area (Villa, 1999; Villa et al., 1999). A similar study conducted on the lagoon by Casini et al. (2003) reported lower brain AChE activities in grass goby samples from the western basin near the AR (Casini et al., 2003).

Concerning the effects of contaminant exposure on grass goby ovarian development, all specimens collected from both basins showed GSI values of approximately $20 \%$ of body weight. This is consistent with findings from light microscopy, in which a fully mature state of ovaries is described. GSI values calculated in fish from site STP were higher compared to those from site AC: $7.17 \pm 2.02$ (STP) and $4.29 \pm 4.1(\mathrm{AC})$, while fish from site AR showed GSI values comparable to those from STP $(5.77 \pm 4.37)$. According to Giulianini et al. (1992), ovarian histology revealed ripe ovaries filled with oocytes at all stages of development: early and late perinucleus, yolk vesicles, primary, secondary and tertiary yolk stage and eggs. The presence of at least two populations of oocytes at different developmental stages and oocytes at all stages of development only in the ripe ovary is considered to be indicative of a "group synchronous ovary" (Nagahama, 1983). Mature eggs have a distinct circular profile and a mean diameter of $705 \pm 31 \mu \mathrm{m}(n=10)$; the animal pole is occupied by a layer of ooplasm covering the yolk solid mass, and the micropylar area exhibits typical filaments. Even if vitellogenic oocytes showed a morphological structure referable to the literature (Pilati, 1950), the diameters of oocytes and eggs of all grass goby samples collected from Orbetello lagoon were smaller than those reported for the same species in the North Adriatic Sea (Giulianini et al., 1992, 1994) Table 1) Fig. 6a-c. In a previous study on fish exposed to sub-lethal doses of various contaminants, including OPs, CBs and OC pesticides (endosulfan), ovarian alterations such as smaller diameter of oocytes compared to control fish are reported (Rastogi and Kulshrestha, 1990). Because it is related to the amount of nutrient stored in the form of vitellogenin, variation in egg size could affect the number of offspring produced. The occurrence of smallersized eggs supports the suspected high exposure levels of both AChE-inhibiting OPs and CBs and of OCs, particularly of PCNs and PCBs, in fish from the western basin (sites AR and STP, respectively).

The results of OCs and NPs detected in the ovaries showed strong differences among sampling sites and showed that DDTs were the most accumulated compounds. HCB levels were higher in samples from site STP (0.24 \pm
$0.03 \mathrm{ng} \mathrm{g}^{-1}$ w.w.), followed by those from the Albegna river delta (site AR) and the Ansedonia canal ( site AC) $(0.15 \pm 0.01$ and $0.14 \pm 0.01 \mathrm{ng} \mathrm{g}^{-1}$ w.w., respectively). In contrast, DDTs and PCBs were higher and correlate significantly $(r=0.65)$ in samples from sites $\mathrm{AR}(53.5 \pm 5.3$ and $32.27 \pm$ $3.2 \mathrm{ng} \mathrm{g}^{-1}$ w.w., respectively) and AC (71.76 \pm 7.1 and 40.85 $\pm 4.1 \mathrm{ng} \mathrm{g}^{-1}$ w.w., respectively), while they were lower in site STP $\left(32.7 \pm 10.6\right.$ and $22.35 \pm 7 \mathrm{ng} \mathrm{g}^{-1}$ w.w., respectively), as previously observed in liver tissue. $p$-NP was particularly high in samples from site STP $\left(15.54 \pm 7.98 \mathrm{ng} \mathrm{g}^{-1}\right.$ w.w. $)$, followed by levels in fishes from sites AR and AC (13.04 \pm 12.55 and $8.07 \pm 7.6 \mathrm{ng} \mathrm{g}^{-1}$ w.w., respectively), confirming the observation in muscle tissue. Similar higher NP1E levels were measured in samples from sites AR and STP (25.9 \pm 14.14 and $23.54 \pm 22.98 \mathrm{ng} \mathrm{g}^{-1}$ w.w.) than in those from site AC $\left(11.1 \pm 6.37 \mathrm{ng} \mathrm{g}^{-1}\right.$ w.w.), while no differences among sites were found for NP2E (mean levels of $8.70 \pm$ $2.3 \mathrm{ng} \mathrm{g}^{-1}$ w.w.).

The accumulation of OCs and NPs in fish ovaries may have negative effects on egg and larval viability or larval fitness. If greater exposure occurs in a "critical window" of oestrogen sensitivity such as during vitellogenesis, hydrophobic compounds, like OCs and $p$-NP, could affect egg ontogenesis, resulting in malformed or unviable larvae (Kime, 1997). Hansen et al. (1985), in a study on herrings from the German Baltic coast, found DDT and PCB threshold levels (18 and $120 \mathrm{ng} \mathrm{g}^{-1}$ w.w., respectively) affecting egg and larval viability that were lower than levels detected in grass goby ovaries in the present study. In particular, high DDT levels such as those measured in ovaries of grass gobies from the $\mathrm{AC}\left(71.96 \pm 0.01 \mathrm{ng} \mathrm{g}^{-1}\right.$ w.w. $)$ might affect the reproductive success of the species. Although there is no cause-effect relationship between the levels detected in tissues and reproductive effects, smaller size of grass goby eggs might be related to limited supply of vitellogenin, either due to a dietary restriction or due to noxious conditions in the lagoon ecosystem (Kime, 1997; Corsi and Focardi, 2002).

\section{Conclusion}

The results of this study, in which biological markers and biological tissue content of common aquatic contaminants were integrated, suggest that exposure to xenobiotic compounds in the Orbetello lagoon has a spatial distribution and might account for toxicity and detrimental effects on fish reproduction. Fish sampled in the western basin at the STP site seem more likely to be exposed to P450-inducing organic contaminants, as suggested by the high metabolic (SLI) and 


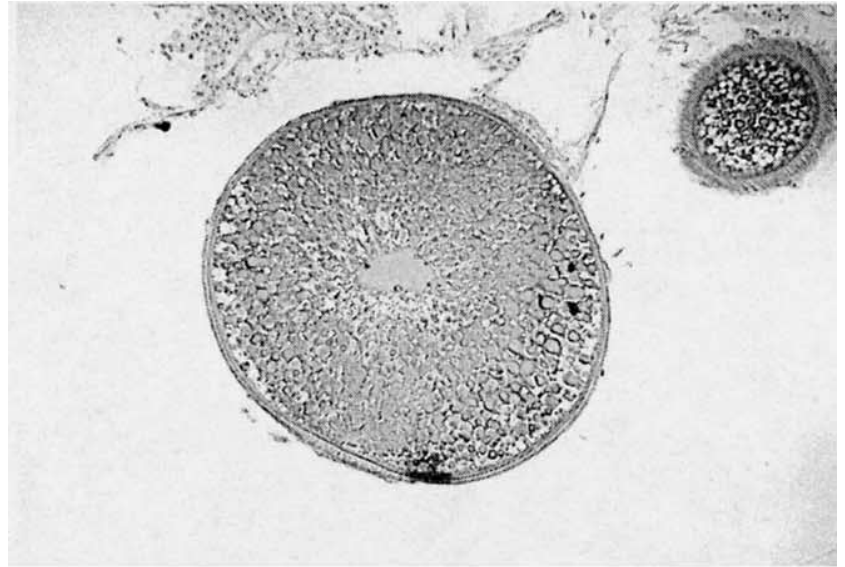

$6 a$

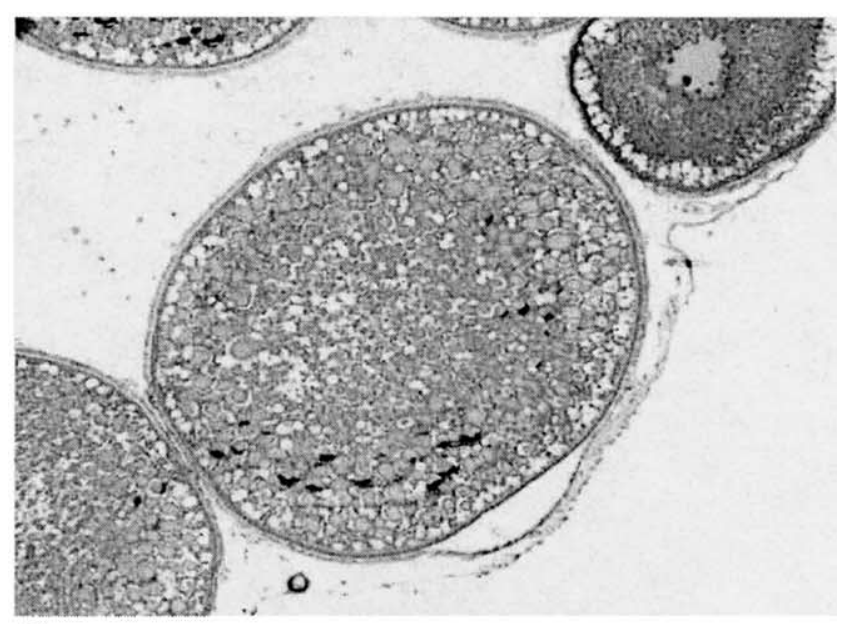

$6 b$

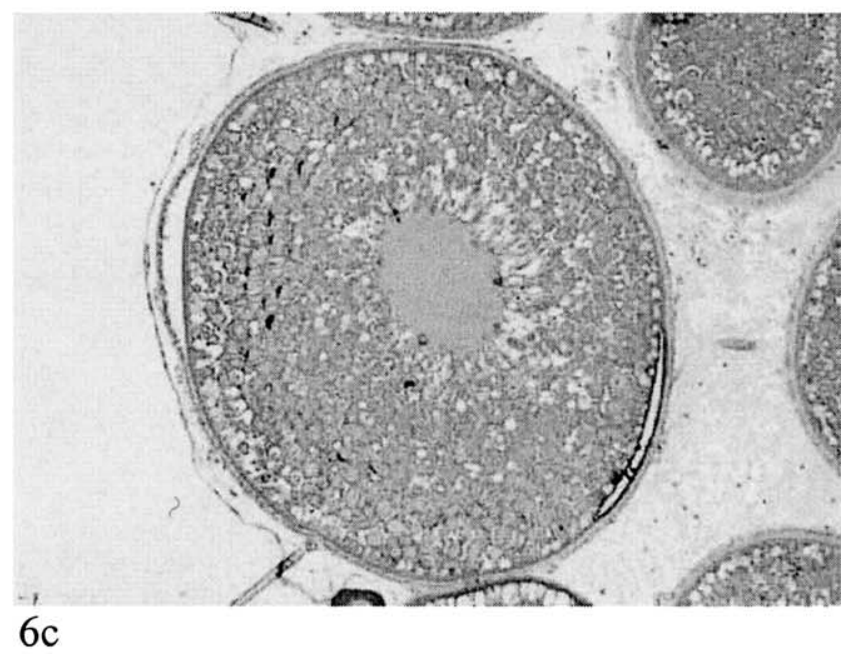

Fig. 6. Cross section of an oocyte at the tertiary yolk stage, with circular profile and largest yolk globules, collected from the three investigated sites: (a) from STP, (b) from AC and (c) from AR; X137.

detoxifying (EROD and BaPMO) activities. However, the high levels of NPs, both in muscle and in ovaries, associated with the highest GSI values observed in this site do not allow us to rule out potential repercussion on sexual differentiation, with reproductive anomalies such as smaller oocytes. Likewise, high levels of OCs, both in liver and in ovaries, associated with low detoxifying activity such as those observed in fish from AC and, in particular, the high DDT levels in ovaries above threshold levels may also be able to affect the reproductive success of fishes. Moreover, in the western basin, low AChE activities observed in fish sampled at the AR are a further confirmation of the release of $\mathrm{OP}$ and $\mathrm{CB}$ insecticides associated with high levels of HCB, which seem related to the agricultural runoff into the river. In this respect, evidence of loss of biodiversity and high rates of fish die-offs reported in the Orbetello lagoon over the past years (Cognetti and Maltagliati, 2000) point out a detrimental role of contaminant exposure in this ecosystem, which should be addressed in future investigations on the lagoon. In fact, a survey of concentrations of sediment pollutants, including trace metals and chlorinated and aromatic hydrocarbons, collected from seven sites in both lagoon basins is under way. Regarding the potential use of this monitoring approach for defining pollution control policies and conservation strategies of lagoon ecosystems, the overall results obtained may be useful in identifying the source of chemicals released into the lagoon (the STP and Albegna river runoff) and their toxic repercussion on fish fauna. In conclusion, the biomarker approach based on multiple stress response integrated with chemical residues in biological tissues not only reveals differences in the health status of fish throughout the lagoon, but also characterises the effects of human activities on shallow water basins.

\section{Acknowledgements}

This study was funded by a 1999 grant from Italy's Ministry of University and of Scientific and Technological Research "Biodiversity conservation and sustainable management of brackish water biotopes along Italian coasts". We thank Prof. Aristeo Renzoni for reviewing and commenting on the manuscript. We thank the fishing co-operative "La peschereccia", in particular Dr. Lenzi and his staff, for their assistance throughout the sampling campaign. We appreciate the assistance of Riccardo Chiea, Lucia Tagliaferro, Valentina Menchi, Monica Malossi and Dr. Enrica Franchi for their valuable laboratory assistance. We appreciate Lucy Anne Bonelli for revising the English.

\section{References}

Adams, S.M., Shepard, K.L., Geeley Jr, M.S., Jimenez, B.D., Ryon, M.G., Shugart, L.R., McCarthy, J.F., 1989. The use of bioindicators for assessing the effects of pollutant stress on fish. Mar. Environ. Res. 28, 459-464.

Adams, S.M., Bevelhimer, M.S., Greeley Jr, M.S., Levine, D.A., Teh, S.J., 1999. Ecological risk assessment in a large river-reservoir: 6. Bioindicators of fish population health. Environ. Toxicol. Chem. 6 (18), 628-640.

Bradford, M.M., 1976. A rapid and sensitive method for the quantification of microgram quantities of protein utilising the principle of protein-dyebinding. Anal. Biochem. 72, 248-254. 
Bucci, M., Gorelli, V., Vincenzi, D., 1988. Risanamento Ambientale della Laguna di Orbetello: Studi Idrologici e Idrogeologici. ENEA, RT/PAS/88/10, Rome p. 196.

Burke, M.D., Mayer, R.T., 1974. Ethoxyresorufin: direct fluorimetric assay of a microsomal- $O$-dealkylation which is preferentially inducible by 3-methylcholantrene. Drug Metab. Dispos. 2, 583-588.

Casini, S., Fossi, M.C., Focardi, S., Leonzio, C., Lari, L., Mattei, N., Corsolini, S., 1994. L'utilizzo dello Zosterisessor ophiocephalus come indicatore della presenza di alterazioni ambientali generate da composti xenobiotici liposolubili nella Laguna di Venezia. Biol. Mar. Mediterr. 1, 339-340.

Casini, S., Corsolini, S., Focardi, S., Fossi, M.C., Mattei, N., 1995. Biomarkers and organochlorines levels in specimens of Zosterisessor ophiocephalus from the lagoon of Venice as a tool for evaluating the water quality. S.It.E. Proc. 16, 61-63.

Casini, S., Cimino, G., Fossi, M.C., Focardi, S., 2003. Use of biomarkers in fish fauna for assessing anthropogenic impact on Orbetello lagoon. Biol. Mar. Mediterr.

Cognetti, G., Maltagliati, F., 2000. Biodiversity and adaptive mechanisms in brackish water fauna. Mar. Pollut. Bull. 40, 7-14.

Corsi, I., 1995. Biomarkers for the evaluation of toxicological risk of contaminants in marine ecosystem: Carcinus aestuarii as bioindicator organisms. Degree Thesis. University of Siena, Italy.

Corsi, I., Focardi, S., 2002. Nonylphenol in a lagoon environment: 4-nonylphenol and nonylphenol ethoxylates in fish tissues. Bull. Environ. Contam. Toxicol. 68, 908-914.

Corsi, I., Aurigi, S., Focardi, S., 2001. Toxicological evaluation of organochlorine levels on some fish specimens from Adriatic sea. In: Faranda, F.M., Guglielmo, L., Spezie, G. (Eds.), Mediterranean Ecosystems: Structures and Processes. Springer-Verlag, Milan, pp. 71-76.

Corsolini, S., Focardi, S., Kannan, K., Tanabe, S., Borrell, A., Tatsukawa, R., 1995a. Congener profile and toxicity assessment of polychlorinated biphenyls in dolphins, sharks and tuna collected from Italian coastal waters. Mar. Environ. Res. 40, 33-53.

Corsolini, F., Kannan, K., Tanabe, S., Tatsukawa, R., 1995b. Isomer-specific analysis of polychlorinated biphenyls and 2,3,7,8-tetrachlorodibenzo- $p$ dioxin equivalent (TEQs) in red fox and human adipose tissue from central Italy. Arch. Environ. Toxicol. 29, 61-68.

Depledge, M.H., Fossi, M.C., 1994. The role of biomarkers in environmental assessment (2). Invertebrates. Ecotoxicology 3, 161-172.

Eljarrat, E., Caixach, J., Jimènez, B., Gonzàlez, M.J., Rivera, J., 1999. Polychlorinated naphthalenes in sediments from the Venice and Orbetello lagoons, Italy. Chemosphere 38, 1901-1912.

Ellmann, G.L., Courtney, K.D., Andreas Jr, V., Featherstone, R.M., 1961. A new and rapid colorimetric determination of acetylcholinesterase activity. Biochem. Pharmacol. 7, 82-88.

Focardi, S., Aurigi, S., Corsolini, S., 1996. Livelli di policlorobifenili e di pesticidi clorurati nell'ittiofauna dell'arcipelago delle Isole Eolie. In: Faranda, F.M., Povero, P. (Eds.), Caratterizzazione Ambientale Marina del Sistema Eolie e dei Bacini Limitrofi di Cefalù e Gioia (EOCUMM95). pp. 491-504.

Focardi, S., Fossi, M.C., Leonzio, C., Aurigi, S., Casini, S., Corsi, I., Corsolini, S., Monaci, F., Sanchez-Hernandez, J.C., 1998. Livelli di idrocarburi clorurati, idrocarburi policiclici aromatici, metalli pesanti e biomarkers biochimici nell'ittiofauna del Mare adriatico. Biol. Mar. Mediterr. 5 (Fasc. 1), 800-806.

Fossato, V.U., 1982. Etude des hydrocarbures chlores dans l'environment de la Lagune de Venise. VIes Journees Etud: Pollutions, Cannes. C.I.E.S.M, pp. $465-468$.

Fossi, M.C., Leonzio, C., Focardi, S., 1989. Regulatory detoxication responses in Gobiidae experimentally exposed to PCBs. Ecotoxicol. Environ. Saf. 18, 11-14.
Fossi, M.C., Casini, S., Savelli, C., Lari, L., Corsi, I., Sanchez-Hernandez, J.C., Mattei, N., Franchi, E., Depledge, M., Bamber, S., 1996. Multi-trial biomarker approach using Carcinus aestuarii to evaluate toxicological risk due to Mediterranean contaminants: field and experimental studies. Fresenius Environ. Bull. 5, 706-711.

Fulton, M., Key, P.B., 2001. Acetylcholinesterase inhibition in estuarine fish and invertebrates as an indicator of organophosphorus insecticide exposure and effects. Environ. Toxicol. Chem. 20, 37-45.

Galgani, F., Bocquené, G., 1990. In vitro inhibition of acetylcholinesterase from four marine species by organophosphates and carbamates. Bull. Environ. Contam. Toxicol. 45, 243-249.

Gill, T.S., Pande, J., Tewari, H., 1990a. Enzyme modulation by sublethal concentrations of aldicarb, phosphamidon and endosulfan in fish tissue. Pestic. Biochem. Physiol. 38, 231-244.

Gill, T.S., Tewari, H., Pande, J., 1990b. Use of the fish enzyme system in monitoring water quality: effects of mercury on tissue enzymes. Comp. Biochem. Physiol. 97C, 287-292.

Giulianini, P.G., Di Marcotullio, A., Patzner, R., Ferrero, E.A., 1992. Morphology of oocytes and corpora atretica in Zosterisessor ophiocephalus (Osteichthyes, Gobiidae). Oebalia XVII (Suppl.), 139-140.

Giulianini, P.G., Di Marcotullio, A., Ferrero, E.A., 1994. Light microscopical and ultrastructural cytology of the ovaries in the sea-grass goby Zosterisessor ophiocephalus (Osteichthyes, Gobiidae). Boll. Zool. 61, 135-144.

Goksøyr, A., 1995. Use of cytochrome P4501A (CYP1A) in fish as a biomarker of aquatic pollution. Arch. Toxicol. 17, 80-95.

Goksøyr, A., Förlin, L., 1992. The cytochrome $P$-450 system in fish, aquatic toxicology and environmental monitoring. Aquat. Toxicol. 22, 287-312.

Habig, C., Di Giulio, R.T., 1991. Biochemical characterisation of cholinesterases in aquatic organisms. In: Mineau, P. (Ed.), Cholinesterase Inhibiting Insecticides: Their Impact on Wildlife and the Environment, vol. 2. Chemicals in Agriculture, pp. 19-34.

Ham, K.D., Adams, S.M., Peterson, M.J., 1997. Application of multiple bioindicators to differentiate spatial and temporal variability from the effects of contaminant exposure on fish. Ecotoxicol. Environ. Saf. 37, 53-61.

Hansen, P.D., von Westerhagen, H., Rosenthal, H., 1985. Chlorinated hydrocarbons and hatching success in Baltic herring spring spawners. Mar. Environ. Res. 15, 59-76.

Hellou, J., Warren, W.G., Payne, J.F., 1993. Organochlorines including polychlorinated biphenyls in muscle, liver, and ovaries of cod, Gadus morhua. Arch. Environ. Contam. Toxicol. 25, 497-505.

Innamorati, M., 1998. La laguna di Orbetello: risanamento e gestione conservativa. Biol. Mar. Mediterr. 5, 1352-1361.

Jimenez, B., Hernandez, L.M., Gonzalez, M.J., Eljarrat, E., Rivera, J., Fossi, M.C., 1998. Congener specific analysis of polychlorinated dibenzo- $p$-dioxins and dibenzofurans in crabs and sediments from the Venice and Orbetello lagoons, Italy. Environ. Sci. Technol. 32, 3853-3861.

Jobling, S., Sumpter, J.P., 1993. Detergent components in sewage effluent are weakly oestrogenic to fish: an in vitro study using rainbow trout (Oncorhynchus mykiss) hepatocytes. Aquat. Toxicol. 27, 361-372.

Johnson, L.L., Casillas, E., Collier, T.K., McCain, B.B., Varanasi, U., 1988. Contaminants effects on ovarian development in English sole (Parophrys vetulus) from Puget Sound, Washington. Can. J. Fish. Aquat. Sci. 45, 2133-2146.

Keith, T.L., Snyder, S.A., Naylor, C.G., Staples, C.A., Summer, C., Kurunthachalam, K., Giesy, J., 2001. Identification and quantitation of nonylphenol ethoxylates and nonylphenol in fish tissues from Michigan. Environ. Sci. Technol. 35, 10-13.

Kime, D.E., 1997. Endocrine Disruption in Fish. Kluwer Academic Publishers $397 \mathrm{p}$.

Kurelec, B., Brivtic, S., Rijaved, M., Muller, W.E.G., Zahn, R.K., 1977. Benzo(a)pyrene monooxygenase induction in marine fish. Molecular response to oil pollution. Mar. Biol. 44, 211-216. 
Lardicci, C., Rossi, F., Castelli, A., 1997. Analysis of macrozoobenthic community structure after severe dystrophic crises in a Mediterranean coastal lagoon. Mar. Pollut. Bull. 34, 536-547.

Lewis, M.A., 1991. Chronic and sublethal toxicities of surfactants to aquatic animals: a review and risk assessment. Water Res. 25, 101-113.

Livingstone, D.R., 1996. Cytochrome P450 in pollution monitoring. Use of cytochrome P4501A (CYP1A) as a biomarker of organic pollution in aquatic and other organisms. In: Richardson, M. (Ed.), Environmental Xenobiotics. Taylor \& Francis, London, pp. 143-160.

Livingstone, D.R., Lemaire, P., Matthews, A., Peters, L.D., Porte, C., Fitzpatrick, P.J., Förlin, L., Nasci, C., Fossato, V., Wotton, N., Goldfarb, P., 1995. Assessment of the impact of organic pollutants on goby (Zosterisessor ophiocephalus) and mussel (Mytilus galloprovincialis) from the Venice lagoon, Italy: biochemical studies. Mar. Environ. Res. 39, 235-240.

Lye, C.M., Frid, C.J.L., Gill, M.E., Cooper, D.W., Jones, D.M., 1999. Estrogenic alkylphenols in fish tissues, sediments and waters from the UK Tyne and Tees estuaries. Environ. Sci. Technol. 33, 1009-1014.

Marcomini, A., Pavoni, B., Sfriso, A., Orio, A.A., 1990. Persistent metabolites of alkylphenol polyethoxylates in the marine environment. Mar. Chem. 29, 307-323.

Nagahama, Y., 1983. The functional morphology of teleost gonads. In: Hoar, W.S., Randall, D.J., Donaldson, E.M. (Eds.), Fish Physiology, vol. IXA, pp. 223-275.

Nasci, C., Campesan, G., Fossato, U.V., 1985. Indici fisiologici e biochimici di stress in Zosterisessor ophiocephalus della Laguna di Venezia. Oebalia XI, 883-885.

Nasci, C., Campesan, G., Fossato, V.U., Tallandini, L., Turchetto, M., 1991. Induction of cytochrome $P-450$ and mixed function oxygenase activity by low concentrations of polychlorinated biphenyls in marine fish Zosterisessor ophiocephalus (Pall.). Aquat. Toxicol. 19, 281-290.

Nebert, D.W., Gelboin, H.V., 1968. Substrate-inducible microsomal aryl hydroxylase in mammalian cell culture. J. Biol. Chem. 243, 6242-6249.

Pastor, D., Boix, J., Fernandez, V., Albaigés, J., 1996. Bioaccumulation of organochlorinated contaminants in three estuarine fish species (Mullus barbatus, Mugil cephalus and Dicentrarcus labrax). Mar. Pollut. Bull. $32,257-262$.

Pilati, C., 1950. Osservazioni sull'apparato riproduttore e sulla gametogenesi nel Gobius ophiocephalus Pallas. Arch. Zool. Ital. 35, 171-183.

Porte, C., Albaigés, J., 1993. Bioaccumulation patterns of hydrocarbons and polychlorinated biphenyls in bivalves, crustaceans, and fishes. Arch. Environ. Contam. Toxicol. 26, 273-281.

Pulsford, A.L., Thomas, M.E., Lemaire-Gony, S., Coles, J., Fossato, V.U., Pipe, R.K., 1995. Studies on the immune system of the goby, Zosterisessor ophiocephalus, from the Venice lagoon. Mar. Pollut. Bull. 30, 586-591.
Rastogi, A., Kulshrestha, S.K., 1990. Effect of sublethal doses of three pesticides on the ovary of a carp minnow Rasbora daniconius. Bull. Environ. Contam. Toxicol. 45, 742-747.

Romi, R., Sabatinelli, G., Majori, G., 2001. Could malaria reappear in Italy?. Emerg. Infect. Dis. 7, 915-919.

Stegeman, J.J., Brouwer, M., Di Giulio, R.T., Förlin, L., Fowler, B., Sanders, B.M., Van Veld, P.A., 1992. Molecular responses to environmental contamination: enzyme and protein system as indicators of chemical exposure and effect. In: Huggett, R.J., Kimerle, R.A., Mehrle Jr, P.M., Bergman, H.L. (Eds.), Biomarkers. Biochemical, Physiological and Histological Markers of Anthropogenic Stress. Lewis Publishers, Boca Raton, FL, pp. 235-335.

Sturm, A., da Silvia de Assis, H.C., Hansen, P.D., 1999. Cholinesterases of marine teleost fish: enzymological characterisation and potential use in the monitoring of neurotoxic contamination. Mar. Environ. Res. 47, 389-398.

Talesa, V., Romani, R., Antognelli, C., Giovannini, E., Rosi, G., 2001. Soluble and membrane-bound acetylcholinesterases in Mytilus galloprovincialis (Pelecypoda: Filibranchia) from the northern Adriatic Sea. Chem.-Biol. Interact. 143, 151-166.

Talmage, S.S., 1994. Environmental and Human Safety of Major Surfactants-Alcohol Ethoxylates and Alkylphenol Ethoxylates. Lewis Publishers $374 \mathrm{p}$.

Tricklebank, K.A., 2001. Histological alterations in fish from Sidney reefs: possible biomarkers for environmental effects?. Biomarkers 6, 26-32.

Villa, S., 1999. Risk assessment of non target organisms for the use of pesticides: case study of Orbetello Lagoon. Ph.D. Thesis in Natural and Environmental Sciences. University of Milan, Italy $95 \mathrm{p}$.

Villa, S., Vighi, M., Casini, S., Focardi, S., 1999. Exposure to pesticides in a lagoon ecosystem. XI Symposium on Pesticide Chemistry. pp. 785-793.

Villeneuve, D.L., Kannan, K., Khim, J.S., Falandyzs, J., Blankenship, A.L., Giesy, J.P., 2000. Relative potencies of individual polychlorinated naphthalenes to induce dioxin-like responses in fish and mammalian in vitro bioassays. Arch. Environ. Contam. Toxicol. 39, 273-281.

Wakimoto, T., Tatsukawa, R., Ogawa, T., 1971. Analytical methods of PCBs. J. Environ. Pollut. Contam. 7, 517-522.

Walker, C.H., 1998. The use of biomarkers to measure the interactive effects of chemicals. Ecotoxicol. Environ. Saf. 40, 65-70.

Walters, J.M., Cain, R.B., Higgins, I.J., Corner, E.D., 1979. Cell-free benzo $(a)$ hydroxylase activity in marine zooplankton. J. Mar. Biol. Assoc. UK 59, 553-563.

White, R., Jobling, S., Hoare, S.A., Sumpter, J.P., Parker, M.G., 1994. Environmentally persistent alkylphenolic compounds are estrogenic. Endocrinology 135, 175-182.

Zell, M., Neu, H.J., Ballschmiter, K., 1978. Single component analysis of PCB and chlorinated pesticide residues in marine fish samples. Fresenius Z. Anal. Chem. 292, 97-107. 